\title{
ГЕРМАНИЗМИ У РЕЧНИКУ ЖАРГОНИЗАМА ЈУЖНЕ ПРУГЕ
}

\begin{abstract}
У раду је сагледан корпус германизама у Речнику жаргонизама јужне пруге. Уочено је да је одређени број именица и глагола у прегледаној грађи германског порекла. Анализа је обављена на морфолошком нивоу и обухватала је обраду лексема које су позајмљенице из немачког као језика даваоца. Резултати анализе показали су да су германизми у Речнику највећим делом прилагођени српском језику путем творбеног процеса деривације, тј. путем префиксације и суфиксације. Присутан је број именица које су у српски језик ушле преко немачког језика, те ови интернационализми представљају такође доказ вишевековног контакта између немачког и српског језика.
\end{abstract}

Кључне речи: германизми, жаргон, немачки језик, српски језик, језички контакти.

\section{1. Увод}

Посматрајући језик и лексику једног језика као целину која се непрестано развија захваљујући утицајима многостраних контаката, како културно-историјских тако и економских и политичких, морају се истовремено имати на уму последице које су њихов резултат. Ови контакти и њихови утицаји огледају се у структури једног језика на лексичком, морфолошком, синтаксичком и семантичком нивоу.

Најранији контакти између говорника српског и немачког језика датирају још из 13. века када у Србију долазе Саси и развијају рударство на овом поднебљу. Најснажнији лексички утицај немачког језика на поднебље Србије извршен је током 18. и 19. века након Велике сеобе Срба и за време владавине Марије Терезије и њеног сина Јозефа II, када се доселио велики број Немаца и то првенствено у Банат, а касније и у Бачку 2 . О овим утицајима више се може прочитати у радовима Германизми у Речнику српскохрватског књижевног језика (АЛАНОВИЋ 1999-2001), Германизми у говорима

\footnotetext{
${ }^{1}$ iv.milkic@hotmail.com

2 Детаљније о историјском прегледу контакта немачког и српског језика в. Вулетић Ђурић 2015: 501-502.
} 
југоисточне Србије (ВЛАЈИЋ-ПОПОВИЋ 1993), Германизми у говорном језику Војвођана (МРАЗОВИЋ 1996), Проиес замене језика и промене изазване контактом српског са немачким језиком у говору Срба у СР Немачкој (ВУЛЕТИЋ ЂУРИЋ 2015), Германизми у савременом српском језику, у германославистичкој литератури и у роману Seтper idem Ђорђа Лебовића (КОСТИЋ-ТОМОВИЋ 2017).

\section{2. Раслојавање језика и међујезички контакти}

Раслојавање језика може бити територијално, социјално и функционално. Жаргон, који је предмет обраде овог рада, припада социјалном раслојавању једног језика. Социјално раслојавање језика као производ има социолект и ,заснован је на посебностима појединих слојева друштва који иначе говоре истим општим књижевним језиком. Ти слојеви формирају се према образовању, професији, према полу, према начину живота припадника ужих заједница људи у друштву" (СТАНОЈЧИЋ 2010: 35). Социолекти, у лингвистици познатији као жаргони, представљају речи које су најчешће преузете из књижевног говора, које могу у већој или мањој мери бити измењене на фонетском, морфолошком и синтаксичком нивоу, али се њихова највећа карактеристика уочава у раслојавању на лексичком нивоу.

Вековни језички контакти између српског и немачког језика огледају се између осталог и у броју од 3982 речи које је Б. Голубовић (2007) набројала као део истраживања на тему германизама у српском језику. Лексеме страног порекла могу припадати лексици стандардног варијетета језика примаоца, али и неком социолекту, региолекту или терминологији неке стручне области. Можемо истаћи да бројни германизми тако припадају стандардној лексици на читавом српском говорном подручју - нпр. нем. Ziegel, $m>c p$. иигла, нем. Zink, $n>c p$. иинк, нем. Flasche, $f>c p$. флаша, нем. Falte, $f>c p$. фалта (ЂУКАНОВИЋ 2012: 24-25) итд.

Бројне лексеме, за разлику од наведених, користе се искључиво у деловима српског говорног подручја где је културно-историјски утицај био највећи, пре свега у Војводини, те у такве регионализме спадају нпр. нем. Gang, m-'ходник'> ср. конк-'ходник испред соба на кући', нем.Einfahrt, $f$-'колски улаз'> ср. ајнфорт-'колски улаз у кућу или дворште' или нем. Rindfleisch,n-'говедина' ср. ринфлајш-'кувано животињско или живинско месо, често из супе' (ЂУКАНОВИЋ 2012: 24; ГОЛУБОВИЋ 2007: 95-98).

Лексеме страног порекла у неком језику деле се на позајмљенице (нем. Entlehnung, f или Lehnwort, n) и преведенице или калкове (нем. Lehnübersetzung, f) (ГОЛУБОВИЋ 2007: 66).

Позајмљенице су добијене преузимањем лексема или синтагми из језика даваоца, пролазећи притом кроз неопходан процес прилагођавања ор- 
тографском, фонолошком и морфолошком систему језика примаоца. Пример ортографског прилагођавања или адаптације позајмљеница српском језику било би писање по моделу „пиши као што говориш”, па смо тако у српском језику добили именицу хаузмајстор од немачке „der Hausmeister”. Следећим видом прилагођавања ортографском систему српског језика може се сматрати писање именица које се у немачком обавезно пишу великим почетним словом, док се у српском језику пишу малим почетним словом (флашиа нем. „die Flasche”, мантил нем. „der Mantel”).

Преведенице су настале на тај начин што језик прималац користи страну лексему као модел, узор, али при том користи материјал свог језика како би се направила нова реч. Овај процес најчешће подразумева превођење лаксеме или синтагме, рашчлањивање и, уколико је могуће, замену еквивалентима из језика примаоца. Ђукановић наглашава како је код многих лексема немогуће са сигурношћу одредити да ли су оне заиста преведенице или изворне творенице, чија се структура случајно подудуара са његовим еквивалентом у неком од језика давалаца. Ово важи и за српску лексику а у погледу преведеница из немачког језика (ЂУКАНОВИЋ 2012: 27).

\section{3. Германизми и њихова адаптација у српском језику}

Према Голубовић (2007: 66-76) требало би разликовати два појма: германизме, онда када је немачки језик давалац, и такве германизме Голубовић назива супстанцијалним, и интернационализме, онда када је немачки само језик посредник.

Ђукановић објашњава: „Утицај немачког језика примећује се и код великог броја наших интернационализама, тј. речи које постоје, с различитим изговором али истим или сличним значењем, у већини европских језика. Ове речи су с приближно немачким изговором у наш језик донели наши земљаци који су се школовали у земљама немачког језика, па су се тамо и срели с њима и усвојили их" (ЂУКАНОВИЋ 2012: 28). Овај аутор даље истиче да се интернационализми који су у српски језик ушли преко немачког најлакше могу препознати по изговору графеме $<c>$ као /з/ (нпр. нем. Universität, $f>$ cр. универзитет), а затим и по изговору $<c n>$ и $<c m>$ као /шп/ и /шт/ (нем. Streik, $m>$ cp. umрајк) и по изговору суфикса латинског порекла -tion као /циион (нпр. нем. Nation, $f>$ cp. нација). Поред тога, на немачки као језик посредник указује и суфикс -ирати, од немачког -ieren (нпр. нем. skizzieren > ср. скицирати) (ЂУКАНОВИЋ 2012: 28).

Ако говоримо о фонолошкој адаптацији српском језику постоји број именица које су полуадаптиране због своје обележености консонантским групама нетипичним за српсски језик, као нпр: шnajз, pajx. Супституција је приметна у следећим консонантским групама: sch>š:Schaum>šaum; 
$s t>s ̌ t:$ Stall $>s ̌ t a l a ; q u>k v:$ Quarz $>k v a r c$, Quark> qvark, док се најприметније промене дешавају у групама консонаната на крају речи, као нпр. у речима гешталт, рајф, итимунг, швери. Вокали немачког језичког система су се лако прилагодили вокалном систему српског језика, па су се тако прегласи (нем. Umlaut: ä,ö,ü), гласови специфични за овај језик, прилагодили постојећем вокалном систему језика примаоца. На тај начин су добијене следеће речи: фен < Föhn, гепек < Gepäck, кнедла < Knödel, динстати < dünsten. ${ }^{3}$

Уколико говоримо о врстама речи у погледу позајмљеница из немачког језика, најпре се мисли на именице, потом на глаголе и придеве. У наставку рада осврнућемо се на категорију рода именица у немачком као језику даваоцу и српском као језику примаоцу. У српском језику долази до формирања одређеног рода именице на основу одређеног суфикса. Ово је први корак у морфолошкој адаптацији, па ће тако позајмљенице из немачког језика које се завршавају консонантом у српском језику - бити мушког рода, а оне које завршавају вокалом $a$ - женског рода (МРАЗОВИЋ 1996: 212). Према Речнику Матице српске не постоји ниједна именица средњег рода која је задржала род у српском језику (бириуз „,das Wirtshaus”, ииль „das Ziel”, итд (АЛАНОВИЋ 1999-2001: 304)), иако се још увек, мада ретко, могу пронаћи позајмљенице средњег рода (туце ,, der Dutzen” (ГОЛУБОВИЋ 2007: 158)).

У одређивању рода и броја позајмљених именица одлучујућу улогу преузима граматика, о чему сведочи промена рода која није заснована на семантичким разлозима. Према Мразовић (1996: 212-213) оваквих примера има код немачких именица које се завршавају консонатом и обележне су мушким родом у српском: куплунг ,, die Kuplung”, луфыm ,, die Luft”, као и код именица које су позајмљене без вокала -е: баји ,,die Beize”, шанаи ,, die Schanze”, шраф ,, die Schraube”, веш ,, die Wäsche”. Међутим, постоји и низ позајмљеница које су додавањем суфикса - $a$ адаптиране у именице женског рода у српском језику (нпр. бина „, die Bühnе”, бленда , die Blende”, дозна „die Dose").

Придеви позајмљени из немачког могу, али и не морају, добити деривациони суфикс. У првом случају конгруирају са именицом, а у другом остају непроменљиви.Тако, према Алановићу (2014: 126) имамо читав низ придева којима је додат суфикс - $а к,-a н,-а в$ или -каст (фришак ,frisch", фаличан ,fehlerhaft", софтан „,softan”, штофан „Stoff”, флекав „fleckig”, виикаст ,witzig"). Насупрот томе имамо и појаву броја позајмљеница које су недеривирани позајмљени придеви који описују боје (нпр.браон, грао) или одређена стања (шланк ,,schlank”, швори „,schwarz”) који остају недеклинирани (АЛАНОВИЋ 2014: 126).

Глаголи који су према Речнику Матице српске означени као позајмље-

\footnotetext{
${ }^{3}$ О ортографској адаптацији германизама у српском в. у ГОЛУБОВИЋ 2007: 133, а о фонетској адаптацији у ГОЛУБОВИЋ 2007: 133-149.
} 
нице из немачког језика су малобројни. Ово је разумљиво уколико се има у виду да је већина позајмљених немачких глагола високо адаптирана у српски језик процесом деривационе префиксације (МРАЗОВИЋ 1996: 213). Ово би значило да су глаголи као врста речи једини који су се морали потпуно адаптирати с обзиром на то да су сви морали добрити суфикс -mu, који је инфинитивни суфикс у српском језику. На овај начин су ове позајмљенице могле задржати своју примарну функцију, а то је функција предиката.

Осим инфинитивног суфикса - $m u$, позајмљени глаголи добијају на корен речи још и следеће суфиксе - , -ира, -ну или -ова (duнстати, ,dünsten, гланияати „glänzеn”, хефтати „,heften”, коштати „kosten”, адресираmи „adresieren”, лакирати „lackieren”, панирати „,panieren”, пасовати „passen”, пелцовати „pelzen”) (АЛАНОВИЋ 2014: 126).

\section{4. Жаргонизми}

У корпусу који чине жаргонизми као нестандардни језички варијетет, водићемо се описом жаргонизама Р. Бугарског који жаргоном назива „сваки неформални и претежно говорни варијетет неког језика који служи за идентификацију и комуникацију унутар неке друштвено одређене групе по професији, социјалном статусу, узрасту и слично - чије чланове повезује заједнички интерес или начин живота, а која уз то може бити и територијално омеђена. Жаргон је обележен специфичним језичким средствима, пре свега лексичким и фразеолошким, а изузетно и граматичким и фонолошким.” (БУГАРСКИ 2006: 12).

Жаргони су врло распрострањени па се њихова употреба може уочити на свим нивоима комуникације, како у формалним тако и у неформалним ситуацијама, код млађих и старијих генерација. Једна од главних карактеристика жаргона је брзина његове промене. Жаргонске речи нестају једнаком брзином којом су и настале. Андрић наводи да су „раније [...] жаргонски изрази или остарели са генерацијом која их је лансирала или су бивали остављени млађој, док је претходна, старећи, прала руке од њих; данас млади не чекају да се реч излиже, да се сасуши...” (АНДРИЋ 1976: 6).

Некада је жаргоном сматран улични говор, говор необразованих и полусвета, док је данас схваћен као говор младих. Недовољан број истраживања на тему жаргона на нашим просторима може се разумети управо тиме да се заборавља чињеница да је жаргон заправо социолект, и да се односи на комуникацију која се одвија унутар одређене социјалне групе.

Како је лексика жаргона подложна брзим променамама нове речи настају било употребљавањем страних речи са новим значењем, прихватањем страних речи у изворном или измењеном облику, али у пренесеном значењу, измишљањем нових речи по узору на постојеће, било као резултат 
асоцијације на неке карактеристичне особине речи. Говорећи о жаргонима Р. Бугарски наглашава да се жаргон одликује ,jезичко стилским својствима као што су лексичка продуктивност и иновативност, граматичка флексибилност, семантичка експресивност (нарочито у правцу пејоративности и ироније), потом метафоричност и асоцијативност, те хуморно поигравање звуком и значењем - неретко са сасвим неочекиваним, па и апсурдним решењима која управо зато делују ефектно" (БУГАРСКИ 2006: 21).

Територијално раслојавање језика које је приметно у жаргону младих нарочит је изазов за истраживаче, а посебно уколико је жаргон обогаћен позајмљеницама. Не тако велики број радова на тему германизама у српском жаргону је објављен протеклих деценија, а једини рад који се бавио германизмима на подручју јуоистока Србије је рад Ј. Влајић-Поповић (1993).

\section{5. Анализа}

У наставку рада представићемо анализу лексема које су узете из дела Речник жаргонизама јужне пруге Јордане Марковић и Татјане Трајковић у издању Филозофског факултета Универзитета у Нишу 2018. године. Морамо истаћи да су ауторке речника у уводној напомени нагласиле да се ради о збирци жаргонских лексема забележених на простору југоисточне Србије и да се термином јужна пруга тежило избегавању дефинисања конкретног простора.

Приликом увида у дело може се уочити да је присутан велики број англицизама, што је разумљиво с обзиром на чињеницу да су популацију која је интервјуисана приликом прикупљања грађе за Речник чинили углавном испитаници млађе доби, ученици, студенти са поменутог простора. Следи преглед грађе ексцерпиране из датог корпуса са циљем идентификовања германизама (Прилог 1).

На основу идентификованих примера можемо установити да је у делу избројан 61 германизам, од чега је 38 именица, 22 глагола и 1 придев. Све лексеме за које је утврђено да су пореклом из немачког језика су позајмљенице, у делу нема преведеница. У раду ће бити дат осврт на неке од ових позајмљеница.

Међу именицама које су позајмљенице из немачког јављају се оне које су преузете у потпуно истом облику које имају у језику даваоцу, као у примерима балкон и тепих.

Занимљивост код свих наведених примера је да су именице задржале исти род које су имале у језику даваоцу. Такве примере наводимо:

гастарбајтер м. особа која ради у иностранству - нем. Gastarbeiter (in) $m(f)$ - гаsтарбајтер (ка) $m(f)$, inostrani (-a) radnik (-ica) (НИКОЛИЋ 2010: $337)$; 
штребер м. онај који пуно учи - нем. Streber $m$ - karijerista m, laktaroš m; (in der Schule) štreber(ka) m(f) (НИКОЛИЋ 2010: 779).

Наведеним именицама можемо додати именицу швец̧а која је такође задржала исти род именице у српском језику, али је подлегла процесу скраћивања, које, како наводи Бугарски (1995), припада творбеним процесима који нису тако чести, носе посебна стилска обележја и нарочито су популарни у омладинском жаргону (БУГАРСКИ 1995: 114).

швеца ж. сестра - нем. Schwester $f<-n>-1$. (Verwandte) sestra $f ; 2$. (Krankenschwester) medicinska sestra f; 3. (Nonne) časna sestra f; 4. (in der Anrede) drugarica fforma obraćanja (НИКОЛИЋ 2010: 725).

Анализирајући даље можемо навести и именицу хери која је у потпуности задржала облик из немачког као језика даваоца, али је подлегла морфолошкој адаптацији у виду промене рода именице, а према правилу о роду именице према консонантском завршетку у српском језику нпр.:

херц м. Срце - нем. das Herz $n t<-e n s,-e n>1$. (Organ) srce $n t$; (Seele) duša f./2.(Kern) jezgro nt; (Zentrum) centar m; (Inneres) sržf (НИКОЛИЋ 2010: 414, 415).

Такође, примери попут следећег илуструју именице које су подлегле фонолошком прилагођавању у виду супституције консонантског пара $\mathrm{cm}$ : шт и путем процеса суфиксације, чиме је ова именица добијајући суфикс - $a$ променила род и у српском језику постала именица женског рода:

фешта ж. Забава - нем. das Fest $n t<(e) s$, -e> praznik $m$, svečanost $f$, proslava $f$ (НИКОЛИЋ 2010: 303).

Највећи број именица подлегао је процесу морфолошке адаптације у виду суфиксације, било да је као основа речи позајмљена именица или глагол из немачког језика. Тако имамо примере у којима су посредством суфикса -ер добијене именице мушког рода у српском језику: друкер, шмекер, шминкер, штребер, као и примере код којих се истим творбеним процесом, суфиксацијом, довело до адаптације германизама у именице женског рода у српском језику уз помоћ суфикса - , -ара, -ка: друкара, фолкерка, крагна, буксна.

Када говоримо о именица као најбројнијој врсти речи, међу германизмима бележимо присуство именица које називамо интернационалним германизмима, о којима је било речи у теоријском делу рада (в. т. 3). У анализираном корпусу издвојено је 11 интернационализама, попут именица $n a-$ nагај, позер, скије, шема. Наводимо неколико примера код којих је наведен језик из ког су посредством немачког језика дошле у лексику српског:

акција ж. дружење, журка - nem. Aktion, die;-,-en [lat. actio, Aktie] (DUDEN 1996: 87);

бомба ж.1. дволитра, пластична флаша пива од два литра / 2. згодна девојка, девојка која добро изгледа - nem. Bombe, die; -,-en [frz. bombe < ital. bomba < lat. bombus] (DUDEN 1996: 274); 
балкон м. 1. дебела особа / 2. глупа особа - nem. Balkon, der; $-s,-s$ [frz. balcon< ital.balcone](DUDEN 1996: 203);

хаос м. 1. неред / 2. нешто веома добро - nem. Chaos,das; -[lat.chaos < griech.chaos] (DUDEN 1996: 300).

У наставку анализе наводимо именице код којих је примећено најизразитије померање из семантичког поља језика даваоца. Самим тим речи су добиле нову конотацију или потпуно нови смисао:

буксна ж.в. џоинт - нем. die Büchse $f<-n>-1$. (Behälter) kutija f; 2 (Konservendose) konzerva f; 3.(ugs: Sammelbüchse) kolektor m; (Gewehr) 4. (Gewehr) puška f (НИКОЛИЋ 2010: 187);

крагна ж. досадна особа - нем. der Kragen $<-s,->-$ kragna f (НИКОЛИЋ 2010: 496);

тепих м. 1. превише пијан човек / 2. маљава леђа - Teppich m. - tepih;

тераса ж. глуп човек, интелектуално ограничена особа - Terrase $f$. terasa;

шраф м. бубуљица - нем. der Schraube $f<-n>-1$. (Bolzen) šraf m.; 2 (zast.) vijak; (Umdrehung) zavrtanje n.; 2. Naut propeler m (НИКОЛИЋ 2010: 716).

У наставку анализе бавићемо се глаголима немачког порекла и њиховим нивоом морфолошке прилагођености у Речнику жаргонизама јужне пруге. Међу глаголима је приметан одређен број који су морфолошки адаптирани посредством творбеног процеса префиксације:

залауфа се $\mathrm{c}^{4} 3$ јд. интезивно нешто почне да ради - нем. laufen (gl.) trčati; ići; hodati; kretati se; teći; curiti; protezati se; važiti, vredeti (ГРУЈИЋ, ЗИДАР 1989: 178);

надрука 3 јд. исприча нешто ружно - нем.drücken - pritisnuti, stisnuti; sniziti; ugnjetavati (ГРУЈИТ 1989: 71);

прецвика 3јд. пресече, згњечи - нем. zwicken - štipati, uštinuti (ГРУЈИЋ, ЗИДАР 1989: 327);

прешалтује Зјд. пребаци се - нем. schalten - upravljati slobodno, raspolagati nečim, gospodariti; uključiti struju (ГРУЈИЋ, ЗИДАР 1989: 254);

уштека 3јд. 1. уштеди / 2. сакрије - нем. stecken-staviti, metnuti, nabiti; pričvrstiti, zadenuti (ГРУЈИЋ, ЗИДАР 1989: 277).

Можемо додати, уколико се осврнемо на семантику глагола као лексема, да је код великог броја глагола утврђено исто значење које је лексема

\footnotetext{
${ }^{4}$ Глаголи у Речникужаргонизама јужне пруге нису дати у инфинитиву већ у 3 . л. јд. презента, јер се ради о дијалекатском подручју српског језика које не познаје инфинитив.
} 
имала у језику даваоцу, па тако наводимо примере глагола попут щалта, шлепа се, шлихта се, штека, или примере:

бламира (се) Зјд. брука се - нем. blamieren (sich) - obrukati (se), osramotiti (se) (НИКОЛИЋ 2010: 171);

лиферује 3јд. отараси се - нем.liefern - isporučiti, snabdeti; davati, pružiti (НИКОЛИЋ 2010: 530);

штанцује 3јд. производи у великим количинама - нем. stanzen - 1. pod mašinskim pritiskom proizvoditi, razdvajati / 2. utisnuti u materijal (ГРУЈИТ, ЗИДАР 1989: 276).

Код само неколико глагола, наведеним у следећим примерима, приметно је делимично или потпуно померање значења у односу на њихово значење у немачком као језику даваоцу:

цвика 3јд. плаши се - нем. zwicken - cmeгнymu, štipati, uštinuti (НИКОЛИЋ 2010: 971);

штреба Зјд. пуно учи, учи напамет - нем. streben - težiti, stremiti nес̌ети; nastojati (НИКОЛИЋ 2010: 778).

У анализираном корпусу пронађен је само један придев који се може назвати германизмом. У питању је придев нашминкан који као основу речи користи глагол из немачког језика schminken. Ова позајмљеница је високо морфолошки адаптирана уз помоћ префикса на- и суфикса -ан карактеристичног за придеве у српском језику.

Након обављене анализе можемо утврдити да су германизми који су пронађени у Речнику жаргонизама јужне пруге, по врсти речи глаголи и именице, високо морфолошки прилагођени српском језику, а да је творбени процес деривације уз помоћ префиксације и суфиксације најзаступљенији када говоримо о морфолошком прилагођавању.

\section{6. Закључак}

Германизми у Речнику жаргонизама јужне пруге анализирани су превасходно морфолошки, а анализа је показала да су именице и глаголи добро адаптирани у региону призренско-тимочког дијалекатског подручја. Након изведене анализе у погледу адаптације германизама утврђено је да је највећи број лексема морфолошки адаптиран путем творбеног процеса деривације, како уз помоћ префиксације која је већински присутна код глагола (надрука, прецвика, прешалтује), тако и помоћу суфиксације која је првенствено била неопходан корак у погледу адаптације глагола. Код именица су заступљени примери задржавања облика и рода именице из немачког као језика даваоца (балкон, тепux), примери ортографске адаптације (гастар- 
бајтер), фонетске (фешта) и морфолошке адаптације која је условила род именице у српском као језику примаоцу (друкара, фолкерка, имекер, иминкер, ито.). Семантичка одступања најприметнија су код именица које су супстанцијални германизми (буксна ж. в. цоинт, шраф м. - бубуљииа), али и код инетрнационалих германизама, који су посредством немачког језика доспели у српски (акиија ж. дружење, журка; балкон м. 1. дебела особа / 2. глупа особа).

У раду је, на примеру германизама, приступљено анализи позајмљеница у Речнику жаргонизама јужне пруге и учињен покушај отварања врата будућим радовима у домену семантике германизама у социолектима српског језика.

\section{Цитирана литература}

АЛАНОВИЋ, Миливој. „Германизми у Речнику српскохрватског књижевног језика". Прилози проучавању језика 30-32, (1999-2001): стр. 297-309.

АЛАНОВИЋ, Миливој. „Germanismen im Serbischen: von systemeigenen zu abweichenden morphosyntaktischen Eigenschaften”. U E. Kaczmarska \& M. Nomachi (priredili), Slavic and German in Contrast. Studies from Areal and Contrastive Linguistics. Slavic Eurasian Studies 26, (2014): 117-134. http:// src-h.slav.hokudai.ac.jp/coe21/publish/no26_se-s/contents.html (Последњи приступ 24. 9. 2020.)

АНДРИЋ, Драгослав. Двосмерни речник српског жаргона и жаргону сродних речи. Београд: Београдски истраживачко-графички завод, 1976.

БУГАРСКИ, Ранко. Увод у општу лингвистику. Београд: Завод за уџбенике и наставна средства, 1995.

БУГАРСКИ, Ранко. Жаргон. Београд: Библиотека ХХ век, 2006.

ВЛАЈИЋ-ПОПОВИЋ, Јасна. „Германизми у говорима југоисточне Србије”. Говори призренско-тимочке области и суседних дијалеката. Зборник реферата са научног скупа (Нишка Бања 17-20. 6. 1992). Филозофски факултет у Нишу, Институт за српски језик САНУ у Београду, Центар за научна истраживања САНУ. Универзитет Нишу, Ниш 1993.

ВУЛЕТИЋ ЂУРИЋ, Јулијана. Процес замене језика и промене изазване контактом српског са немачким језиком у говору Срба у СР Немачкој. Необјављена докторска дисертација. Крагујевац: Филолошко-уметнички факултет, 2015. https://nardus.mpn.gov.rs/handle/123456789/5312 (Последњи приступ 24. 9. 2020)

ГОЛУБОВИЋ, Биљана. „Germanismen in Serbischen und Kroatischen”. Slawistische Beiträge 459. München: Otto Sagner, 2007.

ЂУКАНОВИЋ, Јован. „Немачко-српски језички контакти”. Преводилаи 67, 2012: стр. 21-33. 
КОСТИһ-ТОМОВИЋ, Јелена. Germanizmi u savremenom srpskom jeziku, u germanoslavističkoj literaturi i u romanu Semper idem Đorđa Lebovića. Komunikacija i kultura online, Godina VIII, broj 8, 2017. https://doi.org/10.18485/ kkonline. 2017.8.8.4

МРАЗОВИЋ Павица. „Германизми у говорном језику Мађара”. О Лексичким позајмљеницама. Суботица-Београд, 1996: стр. 209-230.

СТАНОЈЧИЋ Живојин. Граматика српског књижевног језика. Београд: Креативни центар, 2010.

\section{Речницุи}

ГРУЈИЋ Бранислав и ЗИДАР Јосип. Речник немачко-српскохрватски српскохрватско-немачки. Обод Цетиње, Медицинска књига Београд, Загреб, 1989.

НИКОЛИЋ Војислав (Ур.), Универзални немачко-српски речник, превод српских еквивалената Валентина Чоловић (и др.) - Београд, Klett, 2010.

DUDEN Deutsches Universalwörterbuch, [Red.Mathias Wermke], 3. bearbeitete Auflage. Mannheim; Leipzig; Wien; Zürich: Dudenverlag, 1996.

DUDEN ONLINE: <https://www.duden.de/woerterbuch> (Последњи преглед 25. 9. 2020)

\section{Извори}

МАРКОВИЋ, Јордана и ТРАЈКОВИЋ, Татјана. Речник жаргонизама јужне пруге. Филозофски факултет Универзитета у Нишу, 2018.

Ivana D. Milošević

\section{GERMANISMEN IM BUCH REČNIK ŽARGONIZAMA JUŽNE PRUGE}

In diesem Artikel werden Germanismen als Lehnwörter im serbischen Jargon analysiert. Der Korpus im Rečnik žargonizama južne pruge enthält den Jargon des dialektisch markierten Gebiets Serbiens. Die Lexeme die in der Arbeit als Germanismen angeschaut wurden, sind Substantive und Verben, die gut an die serbische Sprache angepasst sind. Die Analyse, die hauptsächlich morphologisch ist, ergab die Ergebnisse, die für die künftige Erforschung des deutsch-serbischen Sprachkontakts motivierend sein sollten.

Schlüsselwörter: Germanismen, Jargon, Deutsch, Serbisch, Sprachkontakte. 


\section{Прилог}

У Прилогу наведене су лексеме за које је утврђено да потичу из немачког језика и дати су њихови еквиваленти на српском језику на основу два речника ${ }^{5}$ Речник немачко-српскохрватски српскохрватско-немачки (1989) и Универзални немачко-српски речник (2010).

$\mathbf{A}$

Ајнц м. јединица као оцена - eins - jedan, Eins $f$. - jedinica.

Акција ж. дружење, журка - Aktion f. - akcija, delovanje; kampanja.

\section{Б}

Балкон м. 1. дебела особа / 2. Глупа особа-Balkon m. - balkon.

Бламира (се) Зјд. брука се - blamieren (sich) - obrukati (se), osramotiti (se).

Блиц ( у изразу 'на блиц') на тренутак, на брзину - Blitz m. - munja.

Бомба ж. 1. дволитра, пластична флаша пива од два литра / 2. Згодна девојка, девојка која добро изгледа - Bombe $f$. - bomba.

Брус м. грудњак - Brustf. - grudi, prsa / Brusthalter m. - brushalter.

Буксна ж. џоинт - Büchse f. - kutija; tegla; puška; skrinja.

\section{$\Gamma$}

Гастарбајтер м. особа која ради у иностранству - Gastarbeiter m. - radnik u gostima.

Д

Друка Зјд. издаје, одаје - drücken - pritisnuti, stisnuti; sniziti; ugnjetavati.

Друкара ж. 1. издајица, цинкарош / 2. свађалица - Druck m. - pritisak; teret.

Друкер м. издајица - види drücken.

Друкне 3јд. ода некога - види drücken.

3

Залауфа се 3јд. интезивно нешто почне да ради - laufen - trčati; ići; hodati; kretati se; teći; curiti; protezati se; važiti, vredeti.

$\mathbf{K}$

Крагна ж. досадна особа - Kragen m. - okovratnik, kragna.

Л

Лер м. неактивно стање (у изразу 'на лер') - leer(adv.) - prazan; nezazuzet; neosnovan.

Лиферује 3јд. отараси се - liefern - isporučiti, snabdeti; davati, pružiti.

Луфтигуз м. беспосличар - Luft f. - vazduh.

\section{M}

Малање с. ликовно васпитање-malen-slikati, naslikati; bojiti, obojiti; namalati. Машина ж. аутомобил - Maschine f. - mašina, naprava, mehanizam, stroj.

Молерисање с. ликовно васпитање - Maler m. - slikar; umetnik (види malen).

\footnotetext{
${ }^{5}$ Библиографски подаци за оба речника налазе се у попису литературе.
} 


\section{$\mathbf{H}$}

Надрука Зјд. исприча нешто ружно - види drücken.

Нацуга се Зјд. напије се - Zug m. - vučenje, vazduh, promaja; let u jatu; kretanje; hod; procesija, litija; voz; potez (u šahu), pogod; zaprega; par; jato krdo; gutljaj; crta(lica); težnja.

Нашминкан м./ нашминкана ж. - 1. особа која има модрице од батина / 2. који је дволичан, неискрен - schminken - šminkati se, doterivati se, ulepšavati se.

П

Папагај м. особа која стално прича исто - Papagei m. - papagaj.

Позер м. 1. неко ко воли да се слика и намешта / 2. особа која држи до спољашњег изгледа - Pose f. - poza, držanje tela (od gl.posen-pozirati).

Прецвика Зјд. пресече, згњечи - види zwicken.

Прешалтује 3јд. пребаци се - види schalten.

\section{$\mathbf{P}$}

рола 3 јд. скита - rollen - kotrljati, uviti, umotati.

C

Скије ж.мн. дугачка стопала - Skier pl. - skije.

\section{$\mathbf{T}$}

Тепих м. 1. превише пијан човек / 2. маљава леђа - Teppich m. - tepih.

Тераса ж. глуп човек, интелектуално ограничена особа - Terrase f. - terasa.

$\mathbf{y}$

Уштека 3јд. 1. уштеди / 2. Сакрије - види stecken.

$\Phi$

Фешта ж. забава - Fest $n$. - proslava, slavlje.

Фолкерка ж. примитивна особа - Volk n. - narod.

Форта 3јд. одуговлачи - vort (adv.) - napred, (ići napred).

Фушер м. лош мајстор - fuscheln/pfuschen - 1.tajno ili brzo trčati naokolo $/ 2$. Varati.

Фушерај м. лоше одрађен посао - види fuscheln/pfuschen.

$\mathbf{X}$

Хаос м. 1. неред / 2. нешто веома добро - Chaos n. - haos.

Херц м. срце - Herz n. - srce.

Ц

Цвика 3јд. плаши ce - zwicken - štipati, uštinuti.

\section{ШI}

Шалта 3јд. мења - schalten-upravljati slobodno, raspolagati nečim, gospodariti; uključiti struju.

Шалтује се 3 јд. пребацује се - види schalten.

Шваба м. Немац - Schwabe m. - oznaka za stanovnika južne regije pod nazivom Schwaben, u srp. Švapska. 
Швеца ж. сестра - Schwester f. - sestra.

Шема ж. у изразу 'бити у шеми', веза - Schema n.- šema; šablon.

Шлепа се Зјд. прилепи се уз некога - schleppen-vući, tegliti.

Шлихта се 3 јд. улагује се, додворава се - schlichten (gl.) - raspraviti, razmrsiti; izgladiti (spor)/schlicht(adj.) - jednostavan, prost; skroman.

Шмек м. специфичност, посебност-schmecken-probati (ukus); okušati; okusiti Шмека Зјд. гледа, заводи - види schmecken.

Шмекер м. млад, леп, привлачан мушкарац - види scmecken.

Шминкер м. особа мушког пола која се много дотерује - види schminken.

Шпрајцеви м. мн. дуге ноге - spreizen-raširiti; rastaviti; raskerečiti (prste-die Finger, noge-die Beine); podupreti; prositi se, šepuriti se, pravitit se važan. Шраф м. бубуљица - Schraub m. - šraf.

Штанцује Зјд. производи у великим количинама - stanzen - 1. pod mašinskim pritiskom proizvoditi, razdvajati / 2. utisnuti u materijal.

Штек м. 1. уштеђевина / 2. тајно, скривено место - stecken - staviti, metnuti, nabiti; pričvrstiti, zadenuti.

Штека (се) Зјд. штеди - види stecken.

Штреба Зјд. пуно учи, учи напамет - streben - težiti, stremiti nečemu; nastojati. Штребање с. учење - види streben.

Штребер м. онај који пуно учи - Streber m. - karijerista, laktaš. 